\title{
The Role Of Motivation In Mediating Competence And Teaching Style Against Accounting Understanding
}

\author{
Sungguh Ponten Pranata ${ }^{1 *}$, Ahmad Rivai $^{2}$, Ballian $^{3}$ \\ ${ }^{1}$ Akuntansi, STIE Mahkota Tricom Unggul, Indonesia \\ 2,3 Manajemen, STIE Mahkota Tricom Unggul, Indonesia \\ ${ }^{*}$ Corresponding author: \\ Email: sungguh.ponten.aritonang@gmail.com
}

\begin{abstract}
.
Understanding of accounting has an important meaning both for students and for universities. The purpose of this research is to determine the direct and indirect effect of competency variables and teaching style on accounting understanding through motivation. This type of research is classified as a cause-and-effect research where this research was conducted at STIE Mahkota Tricom Unggul. As for the target population and sample in this study, they are active in the 2019-2020 school year, amounting to 112 people. Where the sampling technique is quota sampling. Where the sample in this study amounted to 112 respondents. Furthermore, the data collection technique used a questionnaire which was distributed to all samples. The questionnaire measurement scale uses the Likert scale. The results showed that competency had a positive and significant effect on motivation. Teaching style has a positive and significant effect on motivation. Competence has a positive and significant effect on accounting understanding. Teaching style has no effect on students' accounting understanding at STIE Mahkota Tricom Unggul. Motivation has a positive and significant effect on student accounting understanding at STIE Mahkota Tricom Unggul. Motivation has no role in mediating competence in accounting understanding. However, motivation has a role in mediating the teaching style of accounting understanding.
\end{abstract}

Keywords: Competence, Teaching Style, Understanding Motivation

\section{INTRODUCTION}

The development of information technology makes the industrial world need human resources who have good understanding, especially in preparing international standard financial reports [1]. Higher education is the main party in producing these human resources [2]. Higher education institutions also continue to strive to meet the needs of the industrial world through efforts to improve the accounting understanding of their alumni [3]. It is hoped that by providing sufficient provisions to students in the future they will be able to fill the positions needed by the industrial world [4].Having an understanding of accounting for a student who will jump in to fill various positions in the industrial world is very important [5]. Understanding of accounting can be defined as someone who is clever or proficient and understands correctly about accounting [6]. Furthermore, the level of accounting understanding can be measured from the value of accounting courses which include introductory accounting values, intermediate financial accounting values, advanced financial accounting, auditing, and accounting theory. Accounting understanding means the ability to measure, classify (differentiate), and summarize (present) the elements of financial statements [7].An understanding of the importance of taxes by a student can be seen from a conceptual understanding such as the Taxation Law and the ability to calculate taxes. Knowledge and understanding of tax regulations is the process by which taxpayers know about taxation and apply that knowledge to pay taxes.

Knowledge and understanding of taxation regulations that are meant to understand and understand the general provisions and procedures for taxation (KUP) which include how to submit a Tax Return (SPT), payment, place of payment, fines and deadline for payment or reporting of SPT [8]. Furthermore, understanding of taxation is obtained by internal factors (education, interests, experience, age) and external factors (economy, information, culture) [9].The motivation that exists in these students has a function as a driving force from within the individual to carry out certain activities in achieving goals [10]. In addition, motivation is a conscious effort to move, direct and maintain a person's behavior so that he can be motivated to act to do something so that he can achieve certain results or goals [6]. The course objectives for these 
students will of course be different, because each student will have different motivations [11]. Motivation for studying or studying is a factor that is contained within every student [12]. Other people will not know exactly what motivations make a student want to deepen accounting studies [13]. So it is very difficult to understand what is the main reason a student wants to study accounting. However, in this case the motivation can also be changed by factors outside the student [14]. Competence is the ability, skill and skill possessed by a person with respect to his / her job or profession [15].

Furthermore, competence is a statement that describes the appearance of a certain ability that can be observed and measured. Due to this, lecturers must have competence in carrying out their duties [16]. In achieving company goals it is very important to be related to the competencies possessed by employees [17].Teaching style is seen as a broad dimension or personality that includes the position of the lecturer, behavior patterns, mode of performance, and attitudes towards oneself and others. Teaching style is a lecturer style in terms of how lecturers use classrooms, the choice of learning activities and materials, and how to classify their students [18]. Teaching basically means to take students to achieve the goals that have been planned in advance. In practice, the teaching behavior shown by lecturers is very diverse, even though the meaning is the same [19]. If it is traced, the various kinds of teaching behavior of lecturers will get an overview of the general patterns of interaction between lecturers, content, or learning material from students [20].STIE Mahkota Tricom Unggul is one of the campuses that offers a D3 Accounting study program. The high interest of students in choosing this study program is proof that the STIE Mahkota Tricom Unggul campus has different values compared to other campuses. Efforts that have been made so far are by providing a tax certification program as a companion to a diploma. This aims to equip graduates that they are worthy and declared to have competency in the field of taxation. The essence of the problem that has arisen so far is that there are still many students who do not pass the certification exam program from BNSP. Where the certificate is one of the mandatory requirements for students to take part in court proceedings. The following is a list of the percentage of students who have taken the certification exam in the last 3 years:

Table 1. Student Admission Data

\begin{tabular}{|c|c|c|c|}
\hline Year & Number of Students & Graduated & Presentation \\
\hline 2017 & 64 & 28 & $44 \%$ \\
\hline 2018 & 81 & 35 & $43 \%$ \\
\hline 2019 & 112 & 47 & $42 \%$ \\
\hline
\end{tabular}

Source: STIE Mahkota Tricom Unggul (2020)

Based on the table above, it shows that the increase in the number of students is not proportional to the level of the percentage of students passing the BNSP certification exam. Although in the end students are given dispensation for a local certification exam held by a Metro institution under the guidance of STIE Mahkota Tricom Unggul. This indicates that the level of accounting understanding possessed by students has not been good enough to answer the various questions on the certification exam.Motivation of a student to participate in recovery is expected, especially for lecturers. Based on the results of the observations the researcher found that students who had social studies education or accounting vocational schools tended to be less enthusiastic about attending college. Only students with a science education background tend to be enthusiastic. This is what makes motivation affect student behavior.Many factors affect the level of understanding of accounting. The competence of lecturers is often highlighted by management related to how the ability of lecturers to transfer their knowledge to students. So far, management has chosen accounting introductory lecturers with master's qualifications in accounting. It is hoped that lecturers with a background in accounting education will be able to provide good understanding to students. Furthermore, the teaching style of the lecturers is also a material for management evaluation. So far, management chooses lecturers with more experience and teaching hours as the basis for determining lecturers who teach introductory accounting courses.

\section{METHODS}

Path analysis was chosen in this study, because it is considered in accordance with the research topic. Data analysis using SPSS. The population and sample in this study were 112 active students in the 
accounting study program at STIE Mahkota Tricom Unggul in the 2019-2020 school year. Where the sampling technique is quota sampling. Where the sample in this study amounted to 112 respondents. Furthermore, the data collection technique used a questionnaire which was distributed to all samples. The questionnaire measurement scale uses a Likert scale where: 1: Strongly Disagree (STS) 2: Disagree (TS), 3 : Doubt (RR), 4 Agree Once (SS), Strongly Agree at All (SSS) The variables in this study, namely competence, teaching style and facilities, are called independent or independent variables. Understanding is referred to as the dependent variable known as the dependent variable. Motivation is called an intervening variable.

\section{RESULT AND DISCUSSION}

\section{The Effect of Competence on Motivation}

Based on the results of the study, it shows that competence has a positive and significant effect on student motivation at STIE Mahkota Tricom Unggul. This result is certainly not in line with the results of research conducted by [21][22][23] which states that the competence of a lecturer has no effect on students' understanding of accounting. While this study is in line with the results of research [[5][24][25] which states that competence has a positive and significant effect on student motivation at STIE Mahkota Tricom Unggul. The implications of the findings in research on lecturer competence are not only based on formal education, both in undergraduate and master's degree in accounting. Lecturers who work for companies have good ability and analysis when compared to lecturers who are purely academics. It is hoped that lecturers who teach accounting courses will join the Indonesian accounting lecturers association. The goal is that these academic lecturers have additional knowledge and skills and improve their competencies

\section{The Effect of Teaching Style on Motivation}

The results of this study prove that the teaching style has a positive and significant effect on student motivation at STIE Mahkota Tricom Unggul. These results are certainly in accordance with the results of research conducted by [26][27] which states that teaching style has a significant effect on student motivation at STIE Mahkota Tricom Unggul. The implication of the findings in this study is that lecturers who teach at course institutions have a teaching style that is easily understood by students. The accounting practice questions are denser which directly answer the learning objectives. Then the teaching style of this lecturer can be improved through the Pekerti-AA training program. Where it is highly recommended that all lecturers at STIE Mahkota Tricom Unggul before being accepted to teach should be obliged to take part in the PekertiAA training activities.

\section{The Effect of Competence on Accounting Understanding}

The results of this study explain that competence has a positive and significant effect on accounting understanding. This result is not in accordance with the results of research conducted by [28] which states that the competence of a lecturer does not have a significant effect on students' accounting understanding. However, this study is in line with the results of research conducted by [5][29][30] which states that lecturer competence has a significant effect on students' understanding of accounting. The implication of the findings in this research is that lecturer competence in the form of pedagogy tends to have a big role in providing explanations to students in understanding accounting material. Lecturers teach based on problem solving or case studies on companies listed either on the stock exchange or from case studies of company financial reports sourced from journals or print media which are the most appropriate media to improve students' accounting understanding.

\section{The Effect of Teaching Style on Accounting Understanding}

The results showed that the competence of lecturers had a positive and significant effect on students' accounting understanding at STIE Mahkota Tricom Unggul. The results of this study are not in line with the results of research conducted by [26][31][20] which states that teaching styles have a significant effect on students' accounting understanding. Furthermore, the implication of the findings that the researchers got was that the teaching style of lecturers who did not only focus on certain textbooks tended to make students become bored in taking accounting courses. A lecturer is expected to have a good teaching style that is audovisual in which both seeing and hearing the recovery material can be easily understood by students. 


\section{The Influence of Motivation on Accounting Understanding}

Based on the results of data analysis, it shows that motivation has a positive and significant effect on students' accounting understanding at STIE Mahkota Tricom Unggul. The results of this study are in line with previous research conducted by [32][33][34] which stated that motivation has a significant effect on a student's accounting understanding. The implications of the findings in this study indicate that students who have a high school background in science majors tend to have high motivation in attending lectures, especially material on accounting. Students with a high school education background majoring in social studies and vocational school majoring in accounting seem less enthusiastic about taking it. Some students considered that the material had already been obtained, especially in school. So that the focus of some students is no longer on understanding accounting but more on the substance of how to allocate a company's finances or courses such as financial management or investment decision making theory.

\section{The Effect of Competence on Accounting Understanding through Motivation}

Based on the results show that motivation has no role in mediating the competence of student accounting understanding at STIE Mahkota Tricom Unggul. The results of this study reject the research conducted by [35][23] which states that motivation has a role in mediating competence in improving accounting understanding. Then this research is in line with the results of research conducted by [6] which states that motivation has absolutely no role in mediating between competence and understanding of accounting. The implication of the findings in this study is that in increasing the understanding of student accounting, it is better if improvements are made to the competence of the lecturers who will provide lecture material. This effort will directly improve students' accounting understanding at STIE Mahkota Tricom Unggul.

\section{The Effect of Teaching Style on Accounting Understanding through Motivation}

The results showed that motivation has a role in mediating the teaching style of students' accounting understanding at STIE Mahkota Tricom Unggul. The results of this study are in line with the results of research conducted by [26][19] which states that motivation is a variable that has a role in mediating the teaching style variable with accounting understanding. The implication of the findings in this study is that when the teaching style of a lecturer is getting better, it will be able to increase student motivation to study and in the end it will have an impact on increasing the understanding of accounting from students.

\section{CONCLUSION}

Based on the results of the research and discussion above, the conclusions in this study are as follows:

1. Directly competence has a positive and significant effect on student motivation at STIE Mahkota Tricom Unggul.

2. Directly teaching style has a positive and significant effect on student motivation at STIE Mahkota Tricom Unggul.

3. Directly competence has a positive and significant effect on student accounting understanding at STIE Mahkota Tricom Unggul.

4. Directly teaching style has no effect on students' accounting understanding at STIE Mahkota Tricom Unggul.

5. Directly motivation has a positive and significant effect on student accounting understanding at STIE Mahkota Tricom Unggul

6. Indirectly competence has no effect on student accounting understanding through Motivation at STIE Mahkota Tricom Unggul. This means that motivation does not have a role in mediating competence in accounting understanding

7. Indirectly, teaching style has an effect on students' accounting understanding through motivation at STIE Mahkota Tricom Unggul. This means that motivation has a role in mediating competence in accounting understanding. 


\section{ACKNOWLEDGMENTS}

The researcher would like to express his deepest gratitude to the Directorate of Research and Community Service (DRPM) who has provided support in the form of funding for this research. Furthermore, the researcher appreciates all parties involved such as research members, chairmen, lecturers and students of STIE Mahkota Tricom Unggul who have helped the completion of this research in accordance with the set time.

\section{REFERENCES}

[1] N. H. W. A.; P. Permata, "Pengaruh Ketersediaan Sarana Pendidikan Dan Kecerdasan Emosional Terhadap Tingkat Pemahaman IFRS Dengan Minat Sebagai Variabel Moderating Di Fakultas Ekonomi UNSOED,” in Simposium Nasional Akuntansi XIII Purwokerto 2010, 2010, no. 8, pp. 1-23.

[2] N. P. L. G. N. G. P. Wirawati, "Pengaruh Kecerdasan Intelektual, Kecerdasan Emosional, Kecerdasan Spiritual, dan Perilaku Belajar Terhadap Pemahaman Akuntansi,” E-Jurnal Akunt., vol. 28, no. 2, pp. 1377-1404, 2019.

[3] A. A. N. A. Kresnandra, "Pengaruh Perilaku Belajar terhadap Tingkat Pemahaman Akuntansi dengan Kecerdasan Emosional sebagai Variabel Pemoderasi,” J. Akunt., vol. 28, no. 3, pp. 2065-2075, 2019.

[4] A. D. M. Yanti, "Analisis Faktor-Faktor yang Mempengaruhi Tingkat Pemahaman Akuntansi Mahasiswa Jurusan Akuntansi STIE Mikroskil Medan,” J. Wira Ekon. Mikroskil, vol. 5, no. April, pp. 11-20, 2015.

[5] A. M. M. A. Rozak, "Pengaruh Kompetensi Dan Profesionalisme Dosen Akuntansi Terhadap Tingkat Pemahaman Mahasiswa Akuntansi," Res. Artic., vol. 3, no. 1, pp. 1-17, 2019.

[6] N. M. M. P. I. Nugroho, "Pengaruh Hasil Belajar Pengantar Akuntansi Terhadap Tingkat Pemahaman Akuntansi Mahasiswa Prodi Akuntansi UKSW Dengan Motivasi Belajar Sebagai Variabel Moderasi," J. IIm. MEA (Manajemen, Ekon. dan Akuntansi), vol. 4, no. 1, pp. 257-270, 2020.

[7] A. P. R. Sitawati, "Pengaruh Sarana Prasarana Pendidikan Dan Kecerdasan Emosional (Eq) Terhadap Tingkat Pemahaman Akuntansi Mahasiswa Dengan Minat Belajar Sebagai Variabel Intervening (Studi Kasus Mahasiswa AMIK JTC Semarang Angkatan 2012 - 2014)," Infokom, vol. 1, no. 13, pp. 51-60, 2017.

[8] Siti Resmi, Perpajakan Teori dan Kasus, Buku 1 edisi 8. Jakarta: Salemba Empat, 2014.

[9] Notoatmodjo, Perpajakan. Jakarta: Salemba Empat, 2010.

[10] A. F. Nasib, Mengenal Dasar Manajemen. Jawa Tengah: CV. Pena Persada, 2020.

[11] S. Nisa, "Pengaruh Motivasi Dan Sikap Terhadap Minat Mahasiswa Akuntansi Untuk Mengambil Profesi Chartered Accountant (CA) Pada Universitas Islam Swasta Di Kota Medan," J. Mutiara Akunt., vol. 04, no. 1, pp. 49-62, 2019.

[12] M. A. P. A. N. Yushita, "Pengaruh Motivasi Belajar, Minat Belajar, Dan Perhatian Orang Tua Terhadap Prestasi Belajar Akuntansi Siswa Kelas Xi IPS SMA Negeri 1 Prambanan Klaten Tahun Ajaran 2016/2017," J. Pendidik. Akunt. Indones., vol. XV, no. 2, pp. 63-77, 2017.

[13] V. S. Subowo, "Pengaruh Motivasi Belajar, Lingkungan Keluarga Dan Peran Guru Terhadap Disiplin Belajar Siswa," Econ. Educ. Anal. J., vol. 7, no. 1, pp. 29-44, 2018.

[14] A. R. A. Nurkhin, "Pengaruh Fasilitas Belajar dan Keterampilan Mengajar Guru terhadap Hasil Belajar Komputer Akuntansi melalui Motivasi Belajar sebagai Variabel Mediasi,” Liabilities J. Pendidik. Akunt., vol. 2, no. 1, pp. 1-23, 2020.

[15] Trianto, Model Pembelajaran Terpadu Konsep,Strategi Dan Implementasinya. Dalam Kurikulum Tingkat Satuan Pendidikan (KTSP). Jakarta: Bumi Aksara, 2011.

[16] F. B. A. N. R. D. Kristianto, "Pengaruh Kecerdasan Emosional, Kecerdasan Intelktual, Perilaku Belajar, Kompetensi Dosen Dan Fasilitas Pembelajaran Terhadap Tingkat Pemahaman Akuntansi," J. Akunt. dan Sist. Teknol. Inf., vol. 14, no. 2, pp. 351-360, 2018.

[17] A. Wibowo, Aplikasi Praktis SPSS dalam Penelitian. Yogyakarta: Gava Media, 2012.

[18] S. Asra, Sumiati Dan Asra. Bandung: Sumiati Dan Asra, 2011.

[19] A. Listiana, "Pengaruh Pemahaman Perpajakan, Intensitas Pemberian Tugas dan Gaya Belajar Terhadap Hasil Belajar Akuntansi Perpajakan Dengan Motivasi Belajar Sebagai Variabel Moderating Pada Mahasiswa Pendidikan Akuntansi Fakultas Ekonomi Universitas Negeri Surabaya,” J. Pendidik. Akunt., vol. 07, no. 03, pp. 294-300, 2019.

[20] N. M. I. P. N. M. D. Ratnadi, "Pengaruh Kecerdasan Emosional, Gaya Belajar Visual, Gaya Belajar Auditorial Dan Kinestetik Pada Tingkat Pemahaman Akuntansi," J. Akunt., vol. 30, no. 1, pp. 130-146, 2020.

[21] R. W. M. A. P. Prasetio, "Pengaruh Kompetensi Dosen terhadap Prestasi Akademik Mahasiswa Fakultas Ekonomi dan Bisnis Telkom University,” J. Penelit. Pendidik., pp. 94-102, 2018.

[22] Es. S. I. S. Subagio, "Pengaruh Kompetensi dan Pemahaman Sistem Informasi Akuntansi Serta Motivasi Terhadap Kinerja Karyawan,” J. Law, English, and Econ., vol. 01, no. 01, pp. 11-27, 2019.

[23] F. H. S. B. S. A. A. N. . Dwirandra, "Motivasi Sebagai Pemoderasi Pengaruh Kompetensi Dan Teknologi Informasi Pada Penerapan Akuntansi Berbasik Akrual," E-Jurnal Ekon. dan Bisnis Univ. Udayana, vol. 5, no. 8, pp. 2403-2430, 2016.

[24] A. M. R. M. M. A. H. Putra, "Pengaruh Kompetensi Pedagogik Dosen terhadap Motivasi Belajar Mahasiswa Pendidikan IPS,” J. Darussalam J. Pendidikan, Komun. dan Pemikir. Huk. Islam, vol. 10, no. 2, pp. 375-387, 
2019.

[25] F. N. I. ; A. Q. Djaelani, "Pengaruh Kompetensi Dosen Dan Kinerja Dosen Terhadap Motivasi Belajar Mahasiswa Fakultas Ekonomi Dan Bisnis Universitas Islam Malang," e - J. Ris. Manaj., pp. 49-65, 2020.

[26] I. J. A. L. O. Muharram, "Pengaruh Gaya Mengajar Terhadap Motivasi Dan Prestasi Belajar Ekonomi Siswa SMA Negeri Berbasis K-13 Di Kabupaten Konawe Selatan,” J. Wahana Kaji. Pendidik. IPS, vol. 1, no. 1, pp. 56-67, 2017.

[27] L. Cahaya, "Pengaruh Gaya Mengajar Guru Terhadap Motivasi Belajar Siswa Kelas 3 SDN Ngebruk 01 Kecamatan Poncokusumo Kabupaten Malang," in Seminar Nasional PGSD UNIKAMA, 2020, vol. 4, pp. 461471.

[28] R. Hariyani, "Kompetensi Dosen Yang Memengaruhi Tingkat Pemahaman Akuntansi Mahasiswa Akademi Sekretari Dengan Locus Of Control Internal Sebagai Variabel Moderasi,” J. Sekr. Adm., vol. 17, no. 1, pp. 1$14,2019$.

[29] A. Kadir, "Pengaruh Kompetensi Dosen Dan Motivasi Belajar Terhadap Kemampuan Analisis Statistika Mahasiswa Ftik Iain Kendari," Al-Izzah J. Hasil-Hasil Penelit., vol. 13, no. 1, pp. 1-15, 2018.

[30] R. Gumilar, "Pengaruh Kompetensi Pedagogik Terhadap Hasil Belajar Mahasiswa (Penelitian Survey Pada Mahasiswa Pendidikan Ekonomi Pada Mata Kuliah Evaluasi Pembelajaran),” J. Siliwangi, vol. 5, no. 1, pp. 4446, 2019.

[31] I. P. S. R. Sartika, "Pengaruh Perilaku Belajar, Gaya Mengajar Dosen, Dan Kecerdasan Emosional Terhadap Pemahaman Mahasiswa Pada Mata Kuliah Pengantar Akuntansi,” Menara Ekon., vol. IV, no. 2, pp. 39-49, 2018.

[32] V. S. A. A. Hariri, "Pengaruh Motivasi, Self Efficacy, Dan Pemahaman Pada Peraturan Menteri Keuangan No. 111/Pmk.03/2014 Terhadap Minat Berkarir Mahasiswa Akuntansi Sebagai Konsultan Pajak,” E-JRA, vol. 09, no. 01 , pp. $69-84,2020$.

[33] D. H. A. Feranika, "Pengaruh Pengendalian Diri, Motivasi, Perilaku dan Minat Belajar terhadap Tingkat Pemahaman Akuntansi (Studi Empiris Pada Mahasiswa IAI Nusantara Batanghari dan Universitas Dinamika Bangsa Jambi)," BIEJ Bus. Innov. Entrep. Journal, vol. 2, no. 4, pp. 232-241, 2020.

[34] H. Fajarsari, "Pengaruh Motivasi dan Persepsi Terhadap Minat Mahasiswa Mengikuti Pendidikan Profesi Akuntansi ( PPAK ) di Kota Semarang," Pamator, vol. 13, no. 1, pp. 30-43, 2020.

[35] D. S. R. Setiyani, "Pengaruh Kompetensi Pedagogik Guru Dan Fasilitas Belajar Terhadap Prestasi Belajar Melalui Motivasi Belajar," Econ. Educ. Anal. J., vol. 7, no. 2, pp. 390-399, 2018. 